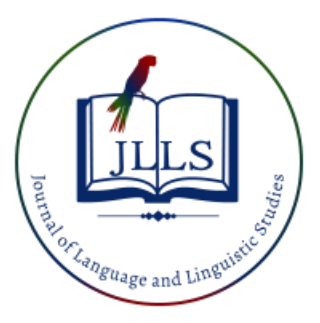

Available online at www.jlls.org

JOURNAL OF LANGUAGE AND LINGUISTIC STUDIES

ISSN: 1305-578X

Journal of Language and Linguistic Studies, 16(4), 1898-1908; 2020

\title{
L2 motivational self-system as predictors of out-of-class willingness to communicate
}

\author{
Noraini Zulkepli a 1 iD \\ ${ }^{a}$ Universiti Pendidikan Sultan Idris, Tanjong Malim, Malaysia
}

\begin{abstract}
APA Citation:
Zulkepli, N.(2020). L2 motivational self-system as predictors of out-of-class WTC. Journal of Language and Linguistic Studies, 16(4), 18981908.

Submission Date: 26/07/2020

Acceptance Date: $08 / 09 / 2020$

Abstract

Empirical studies have long proven the link between speaking and second language learning. Despite its importance in determining one's success to master the target language, willingness to communicate (WTC) is not always high even among motivated and advanced English language learners. This often leads to them not taking the opportunities to engage in verbal activities that are beneficial for them as language learners. The present study seeks to identify the relationship between L2 motivational self-system (the ideal self and the ought-to self) and out-of-class WTC. It draws on a quantitative research design that involved a sample of 111 pre-service ESL teachers in Malaysia. Two major findings were identified. First, even though proficient, their level of out-of-class WTC was only satisfactory not high as expected. Second, the ideal self was the stronger predictor of their out-ofclass WTC. This supports previous findings on the role of ideal self in learners' willingness to communicate. Based on the findings, the present article ends with a pedagogical suggestion.
\end{abstract}

(C) 2020 JLLS and the Authors - Published by JLLS.

Keywords: L2MSS; L2WTC; pre-service ESL teachers; out-of-class; advanced ESL learners

\section{Introduction}

Contemporary instructed language learning approaches emphasize on encouraging learners to actively take part in communicative tasks (Ellis, 2014). However, despite efforts made by teachers to provide such opportunities, it is very common for them to face learners who are reluctant to engage in verbal communication; which is due to various reasons (Zulkepli, Othman, \& Khaja, 2013). The issue of reticence occurs not only among less proficient learners, but also the proficient ones such as preservice ESL teachers (Fahim \& Dhamotharan, 2016; Yousef, Jamil, \& Razak, 2013; Zulkepli, Tajuddin, AlBakri, Atan, \& Bakar, 2019).

Empirical studies have long proven the strong link between speaking and learning a target language (Goh, 2014; Long, 2015; Swain, 2000). This has triggered interest among scholars in the area of

\footnotetext{
${ }^{1}$ Corresponding author.

E-mail address: noraini@fbk.upsi.edu.
} 
willingness to communicate (WTC); resulting in numerous empirical studies that set to investigate the variables that affect this psychological construct (Pawlak, Mystkowska-Wiertelak, \& Bielak, 2016; Shirvan, Khajavy, MacIntyre, \& Taherian, 2019; Zhang, Beckman, \& Beckman, 2018). However, studies done on this area predominantly focus on in-class WTC where learners normally engage in interaction with "familiar interlocutors, such as teachers and peers, in relatively predictable L2 scenarios" (Lee \& Hsieh, 2019, p. 64). To date, there is scanty research on out-of-class WTC where learners will speak with "unfamiliar acquaintances or strangers in somewhat unpredictable situations" (Lee \& Hsieh, 2019: 64); which will be more challenging even for motivated and advanced learners. Thus, the purpose of the study is to identify the link between motivation and WTC among a group of advanced learners i.e., pre-service ESL teachers.

\subsection{Literature review}

\subsubsection{Willingness to communicate}

According to MacIntyre, Dörnyei, Clement and Noels (1998) WTC is "the probability of engaging in communication i.e., speaking when free to choose to do so" (p. 546). WTC originates from studies in the first language (L1) communication field by researchers like Burgoon, McCroskey, \& Baer (Zarrinabadi \& Tanbakooei, 2016). It was then perceived as a stable construct and related to one's personality.

Recognizing the multifaceted nature of L2 learning, MacIntyre et al. (1998) who spearheaded WTC research in the field argue that L2 WTC is not a "simple manifestation" (p. 546) of L1 WTC. They propose a 6-layer pyramid-shaped heuristic model (Figure 1) that they suggest is helpful "in describing, explaining, and predicting" (p. 545) the variables that affect a learner's choice when deciding either to take part or not in verbal communication using the target language. The bottom of the model comprises two clusters of variables: intergroup climate and personality. These are long-term stable influences and are seen as hardly changing (MacIntyre, Clément, Dörnyei, \& Noels, 1998). The upper layers of the model concern situation-specific variables which are short-term. The final point of the pyramid-shaped WTC model is the specific time and situation where the need to speak in the target language emerges. This is where a particular behavioural attention emerges i.e., either to enter a spoken discourse or not. MacIntyre et al. (1998) postulate that at this moment a learner will choose to engage in the verbal discourse on condition that: they have something to say and they have the confidence to say it. This situational view of WTC has triggered interests among scholars to explore various factors that influence this construct.

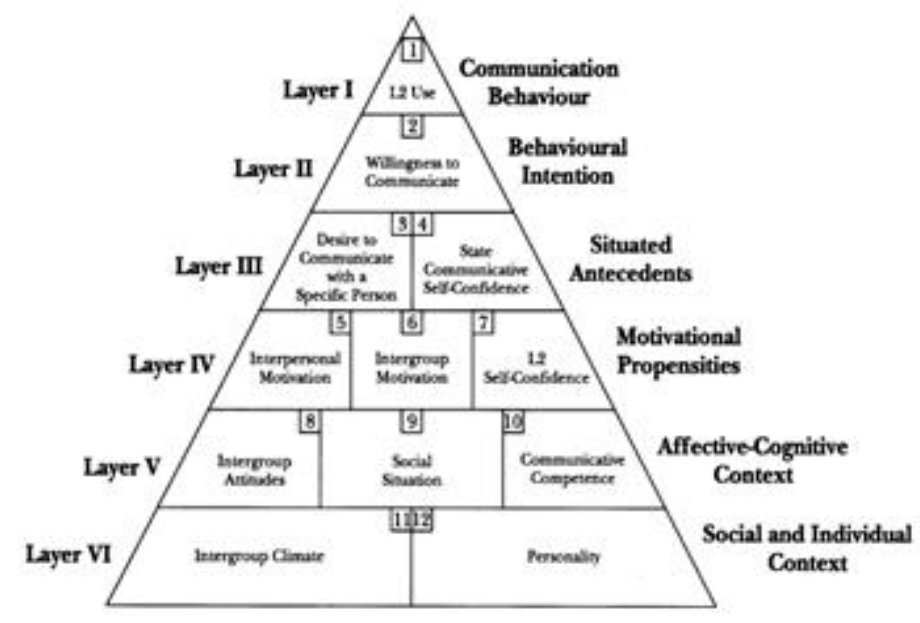

Figure 1. Heuristic model of variables influencing WTC (MacIntyre et al., 1998) 


\subsubsection{L2 Motivational Self System}

Dörnyei (2005) proposes a L2 motivational self system (L2MSS) that aims to describe individual differences in L2 learning. It is drawn from several theories: the possible selves theory, the selfdiscrepancy theory, and the socio-educational model; where among the three, the most influential one is the possible selves theory (Al-Hoorie, 2018). The L2MSS model has three components: the ideal self, the ought-to self, and L2 learning experience.

The ideal self is "the attributes that someone would ideally like to possess" (Dörnyei, 2010: 78). Thus, this dimension of L2MSS represents the learners' hopes and wishes. Kim (2009) views it as the desirable future selves that learners imagine to be upon mastering the target language. Taguchi, Magid, and Papi (2009) add one own hopes and objectives to achieve personal and professional success after acquiring the second language in their description of this L2MSS component. The ought-to self, however, refers to the expectations placed by others on the L2 learners as they (the learners) have mastered the target language. These are attributes that should be possessed in order to fulfil obligations, responsibilities and duties towards the family and society (Dörnyei \& Chan, 2013). The third component is the $\mathrm{L} 2$ learning experience. This refers to the L2 learning situations that learners presently experience which cover a range of "motives related to the immediate learning environment (e.g., the impact of the L2 teacher, the curriculum, the peer group, and the experience of success)" Dörnyei and Ryan (2015, as cited in Dörnyei 2019: 22). Fundamentally, L2MSS works on the premise that it is triggered when a learner is aware of a dissonance between their current situation and their future self-guide (ideal and ought) (Al Hoorie, 2018).

\subsubsection{Past Studies on L2MSS as predictors of L2 WTC}

Empirical studies have been carried out to identify the relationship between L2MSS and WTC, and to determine which one of the future self-guide (ideal or ought) is the stronger predictor of the construct (Darling \& Chanyoo, 2018; Kanat-Mutluoğlu, 2016; Munezane, 2015; Öz \& Bursali, 2018; Peng, 2015; Pourhasan \& Zoghi, 2017). In their quantitative study, Öz and Bursali (2018) carried out a survey on 105 Turkish university students. Results show that there was a statistically significant relationship between the ideal L2 self and L2 WTC, and that the ideal L2 self was the stronger predictor of WTC.

There are also studies that set to investigate the link between WTC and L2MSS focusing on ESL inservice teachers (Bursali \& Öz, 2017; Öz, 2016; Valmori \& De Costa, 2016). In their study, Bursali and Öz (2017) investigated the relationship between the ideal self and WTC. Other than that they also explored the participants' WTC in the four language skills (listening, speaking, reading and writing). Findings show that there was a strong relationship between the ideal self and the pre-service teachers' WTC. The findings also reveal that the participants were more willing to engage in listening, followed by writing, speaking, and reading.

\subsection{Research questions}

The present study investigates a group of pre-service ESL teachers' out-of-class WTC, focusing on L2MSS: the ideal self and the ought-to self as the predictors. Below are the research questions:

1. What is the perceived level of out-of-class WTC among the pre-service ESL teachers?

2. Is there any significant relationship between the participants' L2 MSS and their out-of-class WTC?

a. Is there any significant relationship between the participants' ideal self and their out-ofclass WTC? 
b. Is there any significant relationship between the participants' ought-to self and their out-ofclass WTC?

3. Which one is a stronger predictor of out-of-class WTC among the pre-service ESL teachers (the ideal self or ought-to self)?

\section{Method}

The current study adopts the quantitative research method. Payne and Payne (2004: 180) explain that "quantitative methods (normally using deductive logic) seek regularities in human lives, by separating the social world into empirical components called variables which can be represented numerically as frequencies or rate, whose associations with each other can be explored by statistical techniques..." . Similarly, in this study the L2MSS components (ideal self and ought-to self) and the L2WTC are the variables whose associations are explored by performing statistical tests.

\subsection{Sample}

Samples were selected using the convenient sampling method. It involved 111 ESL pre-service teachers $(16.2 \%$ males, $\mathrm{n}=18 ; 83.8 \%$ females, $\mathrm{n}=93)$. Their reported home languages were: Bahasa Malaysia (84.7\%), Mandarin language (3\%), Tamil language (4\%), English language (5\%) and other languages $(5 \%)$. Consents from the research participants were obtained prior to the distribution of the questionnaire.

\subsection{Instrument}

The present study utilized an adapted questionnaire (Mystkowska-Wiertelak \& Pawlak, 2016) to collect data on the relationship between L2MSS and WTC and to find out the stronger predictor of WTC among a group of pre-service ESL teachers in Malaysia. Through Exploratory Data Analysis (EDA), a preliminary analysis was performed on the data $(n=111)$ where no violation of normality and linearity assumptions was found. To ascertain the internal consistency of the construct items, the Cronbach Alpha was calculated and analyses were performed. The results (as shown in Table 1) indicate that the reliability score is larger than 0.7 , which implies that the items have acceptable consistency (Field, 2013; Pallant, 2007) except for the ought-to self construct. Although the reliability coefficient for the oughtto self is .590, it is deemed as almost reliable as this questionnaire was newly developed (Field, 2013).

Table 1. Reliability analysis of the study variables

\begin{tabular}{|c|c|c|}
\hline Scale & N of Items & Cronbach's Alpha \\
\hline Out-of-class WTC & 7 & 0.754 \\
\hline Ideal L2 Self & 8 & 0.887 \\
\hline Ought-to L2 Self & 3 & 0.590 \\
\hline
\end{tabular}

\subsection{Data collection and analysis}

The data collection was done during a lecture session. The participants were asked to answer the questionnaire anonymously, without any discussion among them. Other than a descriptive analysis, three types of inferential analysis were performed to answer the research questions, below are the details. 
To determine the level of their out-of-class WTC (Research Question 1), the one sample $t$ test was performed. The Pearson correlation coefficient was calculated to determine the relationship between the out-of-class WTC and these pre-service teachers' L2MSS (Research Question 2 (a \& b).To determine the stronger predictor (Research Question 3), a simple regression analysis was done.

\section{Results}

Below are findings from the descriptive analysis.

Table 2. Out-of-class WTC

\begin{tabular}{|l|l|l|l|}
\hline No. & Items & M & SD \\
\hline 1. & I am willing to have a video call to talk to an acquaintance of mine & 3.55 & 1.07 \\
\hline 2. & I am willing to have a video call to talk to a group of my acquaintances & 3.38 & 1.08 \\
\hline 3. & I am willing to initiate communication with someone I met in the street & 3.30 & 1.02 \\
\hline 4. & $\begin{array}{l}\text { I am willing to speak to someone who needs assistance (e.g., help find } \\
\text { directions) }\end{array}$ & 4.19 & .83 \\
\hline 5. & I am willing to initiate communication with a group of people met in the street & 3.03 & 1.05 \\
\hline 6. & I am willing to speak to a group of people who need assistance & 4.05 & .78 \\
\hline 7. & I am willing to use English to speak to my friends out of class & 4.13 & .90 \\
\hline
\end{tabular}

As shown in Table 2, for the 'out-of-class WTC', only three items showed mean score higher than 4; item no. 4, 6 and 7. The obtained results show that item 'I am willing to speak to someone who needs assistance' received the highest mean score $(\mathrm{M}=4.19, \mathrm{SD}=.83)$. However, item 'I am willing to initiate communication with a group of people met in the street' obtained the lowest mean score ( $\mathrm{M}=3.03, \mathrm{SD}$ $=1.05)$.

Table 3. Ideal self

\begin{tabular}{|l|l|l|l|}
\hline No. & Items & M & SD \\
\hline 1. & Whenever I think about my future career, I imagine myself using English. & 4.53 & .62 \\
\hline 2. & $\begin{array}{l}\text { I can imagine myself speaking English as I were a native speaker of the } \\
\text { language. }\end{array}$ & 3.87 & 1.09 \\
\hline 3. & Iimagine myselfas someone whoisable to speakEnglish. & 4.50 & .69 \\
\hline 4. & The things I want to do in the future require me to use English. & 4.55 & .66 \\
\hline 5. & I imagine myself becoming a proficient English teacher. & 4.52 & .71 \\
\hline 6. & Icanimaginea situation where IexplainthingsinEnglishto my students. & 4.59 & .64 \\
\hline 7. & Iimagine taking part in a discussion with other English teachers. & 4.41 & .80 \\
\hline 8. & Iimagineconducting out-of-classactivitiesinEnglishwithmy students. & 4.45 & .77 \\
\hline
\end{tabular}

As indicated in Table 3, for the 'ideal self' construct, all of the items indicated mean score higher than 4 except for item no.2. Item no. 2 'I can imagine myself speaking English as I were a native speaker of the language' showed the lowest mean score $(\mathrm{M}=3.87, \mathrm{SD}=1.09)$. 
Table 4. Ought-to self

\begin{tabular}{|l|l|l|l|}
\hline No. & Items & M & SD \\
\hline 1. & $\begin{array}{l}\text { As a future English teacher, people expect me to be very proficient in the } \\
\text { language. }\end{array}$ & 4.86 & .42 \\
\hline 2. & The society believes that Imust be proficientinEnglish to be an effective teacher. & 4.77 & .56 \\
\hline 3. & $\begin{array}{l}\text { Mastering English is important because other people will respect me when I am } \\
\text { proficient in the language. }\end{array}$ & 4.34 & .94 \\
\hline
\end{tabular}

Table 4 indicates that all of the items for ought-to self section show mean score higher than 4 . The highest mean score goes to item no. 1; 'As a future English teacher, people expect me to be very proficient in the language' with Mean $=4.86, \mathrm{SD}=.42$. Meanwhile, item no. 3 'Mastering English is important because other people will respect me when I am proficient in the language' received the lowest mean score $(\mathrm{M}=3.32, \mathrm{SD}=1.11)$.

Inferential Analysis

\section{R. Q. 1. What is the perceived level of out-of-class WTC among the pre-service ESL teachers?}

Results reveal that the sample mean of 3.659 ( $\mathrm{SD}=.614$ ) was significantly different from the test value. With alpha set at .05 , the one sample $t$ test was significantly different from 3 , with $t(110)=$ 11.30, $\mathrm{p}=.000$. The effect size $d$ of 1.073 indicated a large effect (Green \& Salkind, 2005).

Thus, based on the obtained results, it can be inferred that the level of out-of-class WTC among the pre-service ESL teachers is satisfactory as the mean score $(M=3.659)$ was significantly higher than the test value (with the test value set at 3 ). Furthermore, the effect size of 1.327 signified that the mean score of 3.659 was statistically significantly different from the test value.

R. Q. 2(a). Is there any significant relationship between the participants' ideal self and out-of-class WTC?

Findings indicate that there was a positive significant correlation between these two variables, $r=$ $.289, \mathrm{p}=.001$ at .05 alpha level. The positive sign indicated that as the level of ideal-self increases, the out-of-class WTC will also increase. The $r$ value of .289 indicated that the strength of the relationship was small (Cohen, 2009). Hence, it can be concluded that there was a significant low correlation between the ideal self and the out-of-class WTC among pre-service ESL teachers.

R. Q. 2(b). Is there any significant relationship between the participants' ought-to self and their out-ofclass WTC?

The correlation result shows that there was a minimal positive relationship between these two variables, however, the relationship was not significant, $\mathrm{r}=.071, \mathrm{p}=.229$ at .05 alpha level. Thus, it can be inferred that there was no significant relationship between the ought-to self and the out-of-class WTC among the pre-service ESL teachers.

R. Q. 3. Which one is a stronger predictor of out-of-class WTC among the pre-service ESL teachers (the ideal self or the ought-to self)?

As to comply with Tabachnick and Fidell's (2007) standard of procedure, the correlation between the predictors and the outcome was examined before the regression analysis was performed. This is to 
ensure that all of the predictors were significantly related to the outcome variable prior to including them in the regression model.

The correlation analysis found that only the ideal self was significantly correlated with the out-ofclass WTC $(r=2.89, \mathrm{p}=.001)$. Hence, the ought-to self was excluded in the regression model as it revealed no significant relationship with the out-of-class WTC. The obtained result from simple linear regression analysis indicated that the ideal self was a significant predictor of out-of-class WTC, $\mathrm{R}=$ $.294, \mathrm{R}$ square $=.087, \mathrm{p}=.002$, beta $=.314$.

\section{Discussion}

The study set out to explore L2MSS as predictors of out-of-class WTC among a group of pre-service ESL teachers. Based on the findings, two important observations can be made. First, although the learners were advanced speakers of English, their out-of-class WTC was not high. This suggests that even though they were able to speak the target language well, they will most probably avoid engaging in communicative discourse using English, unless in a circumstance where they were obliged to speak such as when being asked for directions. This rather discouraging result could be considered to be a hindrance to one's further mastery of the target language especially in Malaysia where opportunities to practise the language is aplenty with many who are able to speak English well (Lim, 2019).

Second, the result regarding the low correlation between ideal self and L2 out-of-class WTC indicates that their identity as future ESL teachers does not significantly motivate them to use and practise the language in out-of-class setting. This is rather worrying because as future ESL teachers they need to master the language well especially in Malaysia where quality among Malaysian ESL teachers is defined as possessing not only sound pedagogical competence, but also high proficiency of the target language (Kepol, 2017). The reluctance to use English in out-of-class context could be understood from the concept of 'agency' where learners are seen as active decision makers who "actively engage in constructing the terms and conditions of their own learning" (Lantolf \& Pavlenko, 2001: 145). In a multicultural context such as Malaysia, where it comprises people from different ethnic backgrounds such as Malay, Chinese, Iban, Kadazan, Orang Asli and other indigenous groups (Tajuddin \& Zulkepli, 2019); learners might choose to uphold their ethnic identity by conversing in their mother tongue rather than seizing the available language learning opportunities via verbal engagement in the target language (Rajadurai, 2010; Razak, Nimehchisalem, \& Abdullah, 2018)

The study also found that the ideal self was the stronger predictor of out-of-class WTC. This is quite expected because as teacher trainees, they were more concerned about achieving their personal goal and hopes; not so much about what was imposed by the society.

Based on the results of the study a pedagogical suggestion can be made; which is ESL teacher educators need to encourage their trainees to use the language more frequently outside the classroom setting. Since their ideal self is found to be a strong predictor of their out-of-class WTC, the trainees can be encouraged to set short term goals that are related to their personal hopes as pre-service teachers and language learners. This can be done in class, with some discussion and guidance from the teacher educators.

\section{Conclusions}

To conclude, the level of perceived out-of-class L2 WTC among the pre-service ESL teachers, who were also advanced language learners, was only satisfactory. There was a significant low correlation 
between the ideal self and their out-of-class WTC, however there was no significant relationship between the ought-to self and their L2 WTC. The ideal self was the stronger predictor of the pre-service ESL teachers out-of-class WTC.

\section{Ethics Committee Approval}

The author(s) confirm(s) that the study does not need ethics committee approval according to the research integrity rules in their country (Date of Confirmation: December 11, 2020).

\section{References}

Al-Hoorie, A. H. (2018). The L2 motivational self-system: A meta-analysis. Studies in Second Language Learning and Teaching, 8(4), 721-754.

Bursali, N., \& Öz, H. (2017). The Relationship between Ideal L2 Self and Willingness to Communicate inside the Classroom. International Journal of Higher Education, 6(4), 229-239.

Cohen, J. (2013). Statistical power analysis for the behavioral sciences. Academic press.

Darling, W. E., \& Chanyoo, N. (2018). Relationships of L2 Motivational Self-System Components and Willingness to Communicate in English among Thai Undergraduate Students. NIDA Journal of Language and Communication, 23(33), 1-22.

Dörnyei, Z. (2005). The psychology of the language learner: Individual differences in second language acquisition. Mahwah, NJ: Lawrence Erlbaum.

Dörnyei, Z. (2010). Researching motivation: From integrativeness to the ideal L2 self. In Introducing applied linguistics: Concepts and skills, 3(5), 74-83.

Dörnyei, Z., \& Chan, L. (2013). Motivation and vision: An analysis of future L2 self-images, sensory styles, and imagery capacity across two target languages. Language Learning, 63(3), 437-462.

Dornyei, Z. (2019). Towards a better understanding of the L2 Learning Experience, the Cinderella of the L2 Motivational Self System. Studies in Second Language Learning and Teaching, 9(1), 19-30.

Ellis, R. (2014). Principles of instructed second language learning. In M. Celce-Murcia, D. M. Brinton, \& M. A. Snow (Eds.), Teaching English as a second or foreign language (pp. 31-45). Boston: Heinle.

Fahim, A., \& Dhamotharan, M. (2016). Willingness to communicate in English among trainee teachers in a Malaysian private university. Journal of Social Sciences, 12(2), 105-112.

Field, A. (2013). Discovering statistics using SPSS (4th ed.). London, UK: Sage.

Goh, C. C. (2014). Reconceptualising second language oracy instruction: Metacognitive engagement and direct teaching in listening and speaking. AJELP: The Asian Journal of English Language and Pedagogy, 2, 1-20.

Green, S. B., \& Salkind, N. J. (2005). Using SPSS for Windows and Macintosh: Analyzing and understanding data (4th ed.). Hillsdale, NJ: Pearson.

Kanat-Mutluoğlu, A. (2016). The influence of ideal L2 self, academic self-concept and intercultural communicative competence on willingness to communicate in a foreign language. Eurasian Journal of Applied Linguistics, 2(2), 27-46. 
Kepol, N. (2017). Quality Malaysian English language teachers: Examining a policy strategy. Malaysian Journal of Learning and Instruction, 14(1), 187-209.

Kim, T. Y. (2009). The dynamics of L2 self and L2 learning motivation: A qualitative case study of Korean ESL students. English Teaching, 64(3), 49-70.

Lantolf, J.P. \& Pavlenko, A. (2001). (S)econd (L)anguage (A)ctivity theory: Understanding second language learners as people. In Breen, M.P (Ed.), Learner contributions to language learning. (pp 141-59). Harlow: Pearson Education Limited.

Lee, J. S., \& Hsieh, J. C. (2019). Affective variables and willingness to communicate of EFL learners in in-class, out-of-class, and digital contexts. System, 82, 63-73.

Lim, I. (2019). English proficiency survey puts Malaysia as 'high' but still below Singapore. Malay Mail. Retrieved from https://www.malaymail.com/news/malaysia/2019/12/06/english-proficiency survey-puts-malaysia-as-high-but-still-below-singapore/1816644.

Long, M. (2015). Second Language Acquisition and Task-based Language Teaching. Malden, MA: Wiley Blackwell.

MacIntyre, P. D., Dörnyei, Z., Clément, R., \& Noels, K. A. (1998). Conceptualizing willingness to communicate in a L2: A situational model of L2 confidence and affiliation. The Modern Language Journal, 82(4), 545-562.

Munezane, Y. (2015). Enhancing willingness to communicate: Relative effects of visualization and goal setting. The Modern Language Journal, 99(1), 175-191.

Mystkowska-Wiertelak, A., \& Pawlak, M. (2016). Designing a Tool for Measuring the Interrelationships between L2 WTC, Confidence, Beliefs, Motivation, and Context. In Classroomoriented research (pp. 19-37). Springer, Cham.

Öz, H. (2016). Role of the ideal L2 self in predicting willingness to communicate of EFL students. Research papers as an Additional Language (pp. 163-182).

Öz, H., \& Bursali, N. (2018). The relationship between L2 motivational self-system and willingness to communicate in learning English as a foreign language. Journal of Language and Linguistic Studies, 14(4), 1-11.

Pallant, J. (2007). SPSS survival manual: a step by step guide to data analysis using SPSS. $3^{\text {rd }}$ ed., McGraw-Hill companies.

Payne, G., \& Payne, J. (2004). Key concepts in social research. London: Sage.

Pawlak, M., \& Mystkowska-Wiertelak, A. (2015). Investigating the dynamic nature of L2 WTC. System, $50,1-9$.

Pawlak, M., Mystkowska-Wiertelak, A., \& Bielak, J. (2016). Investigating the nature of classroom willingness to communicate (WTC): A micro-perspective. Language Teaching Research, 20(5), 654-671.

Peng, J. E. (2015). L2 motivational self system, attitudes, and affect as predictors of L2 WTC: An imagined community perspective. The Asia-Pacific Education Researcher, 24(2), 433-443.

Pourhasan, E., \& Zoghi, M. (2017). The role of willingness to communicate and motivation in language learning in Iran. Journal of Language and Translation, 7(1), 59-67.

Rajadurai, J. (2010). "Malays are expected to speak Malay": Community ideologies, language use and the negotiation of identities. Journal of Language, Identity, and Education,9(2), 91-106. 
Razak, F. N. A., Nimehchisalem, V., \& Abdullah, A. N. (2018). The relationship between ethnic group affiliation (EGA) and willingness to communicate (WTC) in English among undergraduates in a public university in Malaysia. International Journal of Applied Linguistics and English Literature, 7(6), 207-213.

Shirvan, M. E., Khajavy, G. H., MacIntyre, P. D., \& Taherian, T. (2019). A meta-analysis of L2 willingness to communicate and its three high-evidence correlates. Journal of Psycholinguistic Research, 48(6), 1241-1267.

Swain, M. (2000). The output hypothesis and beyond: Mediating acquisition through collaborative dialogue. In Lantolf J. P. (Ed.), Sociocultural theory and second language learning (pp. 97-114). Oxford: Oxford University Press.

Tabachnick, B. G., \& Fidell, L. S. (2007). Using multivariate statistics (5th ed.). Boston, MA: Ally \& Bacon.

Taguchi, T., Magid, M., \& Papi, M. (2009). The L2 motivational self system among Japanese, Chinese and Iranian learners of English: A comparative study. In Z. Dörnyei \& E. Ushioda (Eds.), Motivation, Language Identity and the L2 Self (pp.144-163). Bristol: Multilingual Matters.

Tajuddin, A., Amalina, S. N., \& Zulkepli, N. (2019). An Investigation of the Use of Language, Social Identity and Multicultural Values for Nation-Building in Malaysian Outdoor Advertising. Social Sciences, 8(1), 18.

Valmori, L., \& De Costa, P. I. (2016). How do foreign language teachers maintain their proficiency? A grounded theory investigation. System, 57,98-108.Wenger, E. (1998). Communities of practice: learning, meaning and identity. Cambridge: Cambridge University Press.

Yousef, R., Jamil, H., \& Razak, N. (2013). Willingness to communicate in English: A study of Malaysian pre-service English teachers. English Language Teaching, 6(9), 205.

Zarrinabadi, N., \& Tanbakooei, N. (2016). Willingness to communicate: Rise, development, and some future directions. Language and Linguistics Compass, 10(1), 30-45.

Zhang, J., Beckmann, N., \& Beckmann, J. F. (2018). To talk or not to talk: A review of situational antecedents of willingness to communicate in the second language classroom. System, 72, 226239.

Zulkepli, N., Othman, W. M., \& Khaja, F. N. M. (2013). Understanding ESL Learner Participation from the Perspectives of Critical Learning Theories. AJELP: Asian Journal of English Language and Pedagogy, 1, 48-63.

Zulkepli, N., Tajuddin, S. N. A. A., AlBakri, I. S. M. A., Atan, A., \& Bakar, R. M. A. (2019). PreService ESL Teachers' Participation in a virtual community: A positive psychology view. International Journal of Education, 4(33), 122-131. 


\section{Sınıf dışı iletişim kurma istekliliğinin belirleyicileri olarak D2 motivasyonel öz sistem}

\section{$\ddot{O} \mathbf{z}$}

Deneysel çalışmalar konuşma ve ikinci dil öğrenimi arasındaki bağlantıyı uzun zaman önce kanıtlamıştır. Hedef dile hakim olma başarısını belirlemedeki önemine rağmen, motive olmuş ve ileri İngilizce öğrenenler arasında bile iletişim kurma isteği her zaman yüksek değildir. Bu genellikle, dil öğrenenler olarak kendileri için yararlı olan sözlü faaliyetlere katılma firsatlarını değerlendirmemelerine yol açar. Bu çalışma, D2 motivasyonel benlik sistemi (ideal benlik ve kendilik olması gereken) ile sınıf dışı İİ arasındaki ilişkiyi belirlemeyi amaçlamaktadır. Malezya'daki 111 hizmet öncesi İDE öğretmeninden oluşan bir örneklemi içeren nicel bir araştırma tasarımından yararlanmaktadır. İki önemli bulgu tespit edildi. Birincisi, yetkin olsalar bile, sınıf dışı İKİ seviyeleri beklendiği gibi yüksek değil, tatmin ediciydi. İkincisi, ideal benlik, sınıf dışı İKI'lerinin daha güçlü yordayıcısıydı. Bu, öğrencilerin iletişim kurma istekliliğinde ideal benliğin rolüne ilişkin önceki bulguları destekler.

Anahtar Sözcükler: D2 MÖS; D2IKİ; hizmet öncesi İDE öğretmenleri; sınıf dışı; ileri düzey İDE öğrenenler

\section{AUTHOR BIODATA}

Dr. Noraini is a senior lecturer at the Faculty of Languages and Communication, Sultan Idris Education University (UPSI). Her research interests are in the areas of Applied Linguistics and Teacher Education. 